\title{
Study of Profiling the Typical Fraudster in the General Education Sector in Zambia
}

\author{
Paul Bernandicto Ngosa ${ }^{1}$ and Jason Mwanza ${ }^{2}$ \\ ${ }^{1}$ School of Humanities and Social Sciences, the University of Zambia, Lusaka, Zambia \\ ${ }^{2}$ Department of Finance, Ministry of Religious Affairs and National Guidance, Lusaka, Zambia
}

\begin{abstract}
Purpose: The purpose of this paper was to profile who the typical fraudster was in the general education sector.

Materials and Methods: This was a cross-sectional design enlisting staff at provincial and district education offices were enlisted in this study. A standardised survey questionnaire was used. Findings: The sample mean materiality scores were 46.86 ( \pm $S D$ 12.9) and fell below the benchmark of 52 of which fraud could be considered consequential. One sample t test showed a statistically significant difference in perceived fraud materiality in the three groups (Gender of fraudster, age group of fraudster and job type of fraudster) $p$ values were less than 0.05 (0.001). No associations were observed between the three selected demographic variables and materiality of fraud as $p$ values were $>0.05$. Just less than half, $n=238(44.2 \%)$ perceived fraud to be committed by accounting staff and less than half, $n=182(33.8 .8 \%)$ was committed by bosses in league with accounting staff and just less than a quarter $n=119(22.1 \%)$ of fraud was committed by bosses. Males $n=329(61.0 \%)$ were more dominant in committing fraud than were females $n=210$ (39.0\%). The under 30 years age group were perceived to account for just about half $n=239(44.3 \%)$ of fraud whereas the under 31 to 40 years age group were perceived to account for over a quarter $n=211$ (39.1\%) of fraud and far less than a quarter $n=89$ (16.5\%) for those above 40 years. Majority of the fraudsters $n=367(68.1 \%)$ were extroverted as compared to $n=172(31.9 \%)$ were introverted. Fraudsters were perceived with some respect and intelligent. Majority of peers $n=362(67.2 \%)$ considered them on a continuum of Very well respected to being respected as compared to somewhat resected $n=177$ (32.8\%) of all cases surveyed. In more than three quarters of the of all cases surveyed $n=440$ (81.6\%) assessed their peers as fraudsters on a continuum from very impressed as an intellectual to that of being impressed as an intellectual as compared to only $n=99(18.4 \%)$ as somewhat impressed as an intellectual.
\end{abstract}

Conclusion: The typical fraudster in the general educational sector could be mostly an accountant or a boss and holds a senior management position. The fraudster may commit the fraud once they are comfortable in their job and enjoy the trust and respect of colleagues. The fraudster is deemed to be an extrovert, intelligent and has a high level of education.

Key Words: Fraudster, General Education, Demographic, Zambia.

\subsection{INTRODUCTION}

Countries worldwide including Zambia, are struggling with serious challenges of financial management at all levels. The public sector is one area riddled with financial mismanagement. Managers of public schools for instance have been accused of ineffectiveness and inefficiency in terms of resource control (Ndiang'ui, 2012). The Auditor General's reports in Zambia over the years have shown an unending financial mismanagement in the public sector and this is even worse in the general education sector (AG Report, 2017; 2018). A cross cutting analysis of the Auditor General`s reports in the past have revealed an upward trend of gross financial irregularities and embezzlement (Auditor General's Report, 2017). The problem of mismanagement of funds meant for schools results into the withdrawal of major donors from education program and has the potential of locking out so many needy children who benefit from educational funds and rely fully on the program for their educational needs (Ndiang'ui, 2012). The difficulty rests with failure by oversight bodies to come up with the demographic profile of fraudsters which could be used to develop a general framework to mitigate determinants of financial mismanagement or fraud which has resulted in poor service delivery. 
Fraud specialists have long debated whether it is possible to develop a demographic profile of a fraudster that is accurate enough to enable organizations to catch people in the act of fraud or even beforehand. The prediction of a crime before it occurs is, at least for now, the subject of science fiction. But an analysis of the constantly changing nature of fraud and the fraudster can help controlling officers in the public sector in Zambia stiffen their defences against fraudulent activities. This paper is part of the main study that looked at the determinants of financial mismanagement in the general education sector in Zambia. Therefore, the purpose of this paper was to profile who the typical fraudster was in the general education sector.

\subsection{MATERIALS AND METHODS}

The research was done in Zambia, which is a lower middle-income Country. A cross-sectional, descriptive exploratory, quantitative approach structured the design. We opted to employ nomothetic methodology so that we could focus on an examining fraudster type (Putnam, 1983:41) in order to obtain a large adequate representative sample to identify what was true or generalisable to the general population (Grice et al., 2006) in the general education sector. This demanded of us to elicit the patterns of fraudsters by way of quantitative analysis of materiality of fraud (financial mismanagement), demographic variables across the large samples of clusters being the provinces that we had selected relying as much as possible on the guidelines of undertaking case studies (Larsson, 1993: 1515).

The population of the study comprises of staff at provincial and district education offices. The sampling frame was obtained from human resource staff. After screening the sampling frae in each cluster (province), six hundred (600) respondents were eligible for the study. The sample size was determined using Yamane Taro's formula (Yamane, 1967). A standardised survey questionnaire, was developed which covered seventeen financial mismanagement (fraud) variables and these are covered in another paper. We operationalised the fraudster as a person working in the education sector based on geographic location, gender, age and job type. Six hundred (600) copies of the questionnaire distributed and 539 were collected (representing 81.6\% responses).

\subsection{FINDINGS}

Of the 539 public servants who participated in the study, $\mathrm{n}=249(69.4 \%)$ were males and $\mathrm{n}=110(30.6 \%)$ were females and their mean age was $39.3 \pm 4.5$ years. The oldest was 62 and the youngest was 23 years. The levels of education were rather high for the jobs they were performing as more than half $n=351(65.1 \%)$ had certificates and just over a quarter $n=188(34.9 \%)$ had either a diploma or degree. The mean service years in the education sector was 12 ( \pm SD 8.9). There were no marked differences in sample representation in terms of period of service in the four age bands as well as the clusters by province. Table 1 shows some socio-demographic characteristics of the public servants who were in the study.

Table .1: Demographic profile

\begin{tabular}{|c|c|c|}
\hline Social demographic Characteristic & $f$ & $\%$ \\
\hline \multicolumn{3}{|l|}{$\operatorname{Sex}$} \\
\hline Male & 380 & 69.4 \\
\hline Female & 159 & 29.5 \\
\hline \multicolumn{3}{|l|}{ Years of Iservice } \\
\hline $0-5$ years & 149 & 27.6 \\
\hline $6-10$ years & 143 & 26.5 \\
\hline $11-20$ years & 130 & 24.1 \\
\hline Above 21 years & 117 & 21.7 \\
\hline \multicolumn{3}{|l|}{ Level of education } \\
\hline High level of education & 351 & 65.1 \\
\hline Low level of education & 188 & 34.9 \\
\hline \multicolumn{3}{|l|}{ Respondents by Provincial } \\
\hline Muchinga Province & 55 & 10.2 \\
\hline Northern Province & 58 & 10.8 \\
\hline
\end{tabular}


International Journal of Advances in Scientific Research and Engineering (ijasre), Vol 7 (8), August -2021

\begin{tabular}{|l|c|c|}
\hline Luapula Province & 52 & 9.6 \\
\hline Western Province & 49 & 9.1 \\
\hline Lusaka Province & 51 & 9.5 \\
\hline Eastern Province & 57 & 10.6 \\
\hline Copper Belt Province & 53 & 9.8 \\
\hline Central Province & 57 & 10.6 \\
\hline North Western Province & 53 & 9.8 \\
\hline Southern Province & 54 & 10.0 \\
\hline
\end{tabular}

\subsection{Materiality of Fraud}

Before examining the demographic profile of fraud, we first describe the state of fraud using the concept materiality. Noting that fraud is not tolerated at all in the Zambian public service, we computed a composite score which is a summated score derived from an individual's responses to the multiple financial mismanagement (fraud) items. In order to determine the level of materiality of fraud. The scores were used to determine the degree of significance of materiality of fraud. The span of the composite scores for an individual were expected to range from 14 to 70 . Three levels of materiality of fraud were categorised $a$ priori as follows:

a) 14 to 32 was to be considered as high significant levels of materiality of fraud,

b) 33 to 51 was to be considered as low significant levels of materiality of fraud and ;

c) 52 to 70 were to be considered as insignificant levels of materiality of fraud.

We found that the sample mean materiality scores were 46.86 ( \pm SD 12.9). The minimum and maximum scores were 14 and 70 respectively. The mean sample score therefore falls below the benchmark of 52 of which fraud could be considered consequential. We believe that levels below 52 oughts to be qualified as consequential demanding control and once ought to be reported to the audit committee. Generally, the picture portrayed in this study when the composite scores were categorised, only a third of the respondents $\mathrm{n}=179$ (33.2\%) had composite scores above 52 to 70 falling within the insignificant levels of materiality of fraud and $\mathrm{n}=360(66.8 \%)$ vouched for fraud which could be considered consequential (see Table 2$)$.

Table 2: Level of materiality of fraud

\begin{tabular}{|l|c|c|}
\hline \multicolumn{1}{|c|}{ Level of materiality } & Frequency & Percent \\
\hline High significant levels of materiality of fraud & 56 & 10.4 \\
\hline Low significant levels of materiality of fraud & 304 & 56.4 \\
\hline Insignificant levels of materiality of fraud & 179 & 33.2 \\
\hline Total & 539 & 100.0 \\
\hline
\end{tabular}

We then computed materiality of fraud distributions based on the four demographic variables (gender, age of actor, job type of actor, personality as either extroverted or introverted and the level of respect). The materiality scores according to demographic variables were all below the threshold of 52. The male mean scores in all the categories were below the expected benchmark of low significant levels of materiality of fraud (Table 3 ).

Table 3: Variations of materiality of Fraud by Demographic Variables

\begin{tabular}{|l|c|c|c|}
\hline & Mean & Median & SD \\
\hline Age of fraudster & & & \\
\hline Under 30 years & 46.2 & 46.0 & 13.3 \\
\hline 31 to 40 years & 46.6 & 47.0 & 12.9 \\
\hline Over 40 years & 48.8 & 50.0 & 11.5 \\
\hline
\end{tabular}


International Journal of Advances in Scientific Research and Engineering (ijasre), Vol 7 (8), August -2021

\begin{tabular}{|l|c|c|c|}
\hline Gender of fraudster & & & \\
\hline Male & 47.6 & 48.0 & 13.5 \\
\hline Female & 47.2 & 46.0 & 11.7 \\
\hline Job Type of Fraudster & & & \\
\hline Bosses with accounting staff & 46.1 & 49.0 & 14.0 \\
\hline Bosses & 48.5 & 48.0 & 11.7 \\
\hline Accounting staff & 46.5 & 46.0 & 12.5 \\
\hline
\end{tabular}

One sample $t$ tests showed a statistically significant difference in the three as Sig. (2-tailed) were less than 0.05 (0.001) (Table 4).

Table 4: One sample test of finance mismanagement by three demographic variables

\begin{tabular}{|c|c|c|c|c|c|c|}
\hline \multicolumn{7}{|c|}{ Test Value $=52$} \\
\hline & \multirow[t]{2}{*}{$\mathrm{t}$} & \multirow[t]{2}{*}{$\mathrm{df}$} & \multirow[t]{2}{*}{$\begin{array}{l}\text { Sig. (2- } \\
\text { tailed) }\end{array}$} & \multirow[t]{2}{*}{$\begin{array}{c}\text { Mean } \\
\text { Difference }\end{array}$} & \multicolumn{2}{|c|}{$\begin{array}{l}95 \% \text { CI of the } \\
\text { Difference }\end{array}$} \\
\hline & & & & & Lower & Upper \\
\hline Gender of fraudster & -2407.19 & 538 & .000 & -50.61 & -50.65 & -50.57 \\
\hline $\begin{array}{l}\text { Age group of } \\
\text { fraudster }\end{array}$ & -1600.25 & 538 & .000 & -50.27 & -50.34 & -50.22 \\
\hline Job type of fraudster & -853.48 & 538 & .000 & -49.45 & -49.57 & -49.34 \\
\hline Fraud score & -9.24 & 538 & .000 & -5.13 & -6.23 & -4.04 \\
\hline
\end{tabular}

From the distributions above, we set to see what associations existed between the selected demographic variables and materiality of fraud. None of the variables show any association as $\boldsymbol{p}$ values were $>0.05$ (See Table 5).

Table 5: Demographic variables and associations with materiality of fraud

\begin{tabular}{|c|c|c|c|c|c|c|}
\hline & \multicolumn{3}{|c|}{ Category of Materiality of fraud } & \multicolumn{3}{|c|}{ Significant vale } \\
\hline & $\begin{array}{l}\text { High significant } \\
\text { levels of materiality } \\
\text { of fraud }\end{array}$ & $\begin{array}{lr}\text { Low } & \text { significant } \\
\text { levels } & \text { of } \\
\text { materiality } & \text { of } \\
\text { fraud } & \end{array}$ & $\begin{array}{l}\text { Insignificant levels } \\
\text { of materiality of } \\
\text { fraud }\end{array}$ & $\chi^{2}$ & $d f$ & $\begin{array}{c}p \\
\text { value }\end{array}$ \\
\hline Staff & & & & & & \\
\hline $\begin{array}{l}\text { Bosses with } \\
\text { accounting } \\
\text { staff }\end{array}$ & 25 & 94 & 63 & & & \\
\hline Bosses alone & 7 & 69 & 43 & 6.30 & 4 & .17 \\
\hline $\begin{array}{l}\text { Accounting } \\
\text { staff alone }\end{array}$ & 24 & 141 & 73 & & & \\
\hline Gender & & & & & & \\
\hline Male & 30 & 183 & 116 & & & \\
\hline Female & 26 & 121 & 63 & 2.47 & 2 & .29 \\
\hline
\end{tabular}


International Journal of Advances in Scientific Research and Engineering (ijasre), Vol 7 (8), August -2021

\begin{tabular}{|l|c|c|c|c|c|c|}
\hline Age group & & & & & & \\
\hline $\begin{array}{l}\text { Under } \\
\text { years }\end{array}$ & 23 & 142 & 74 & & & \\
\hline 31 to 40 years & 26 & 115 & 70 & 3.52 & 4 & .47 \\
\hline Over 40 years & 7 & 47 & 35 & & & \\
\hline
\end{tabular}

\subsection{Demographic Profile of fraudsters}

We assessed the perceptions of the respondents whom they perceived to be associated with fraud. We found that just less than half, $\mathrm{n}=238(44.2 \%)$ perceived fraud to be committed by accounting staff and less than half, $\mathrm{n}=182(33.8 .8 \%)$ was committed by bosses in league with accounting staff and just less than a quarter $n=119(22.1 \%)$ of fraud was committed by bosses. The sample perceived that males $n=329(61.0 \%)$ were more dominant in committing fraud than were females $n=210(39.0 \%)$. The under 30 years age group were perceived to account for just about half $n=239(44.3 \%)$ of fraud whereas the under 31 to 40 years age group were perceived to account for over a quarter $n=211(39.1 \%)$ of fraud and far less than a quarter $n=89(16.5 \%)$ for those above 40 (Table 6 ).

Table 6: Perceived Actor who is Involved in Fraud

\begin{tabular}{|l|c|c|}
\hline & Frequency & Percent \\
\hline Job type of Actor & & \\
\hline Bosses with accounting staff & 182 & 33.8 \\
\hline Bosses & 119 & 22.1 \\
\hline Accounting staff & 238 & 44.2 \\
\hline Gender of Actor & 329 & 61.0 \\
\hline Male & 210 & 39.0 \\
\hline Female & & 44.3 \\
\hline Age group of Actor & 239 & 39.1 \\
\hline Under 30 years & 211 & 16.5 \\
\hline 31 to 40 years & 89 & \\
\hline Over 40 years & & \\
\hline
\end{tabular}

\subsection{Other attributes of Fraudsters}

We looked at three attributes of fraudsters and these were Personality, level of resected and intellect accorded to the perceived fraudsters. Majority of the fraudsters $n=367(68.1 \%)$ were extroverted as compared to $n=172(31.9 \%)$ were introverted. Their peers perceived them with some respect and intelligent. Majority $n=362(67.2 \%)$ considered them on a continuum of Very well respected to being respected as compared to somewhat resected $n=177$ (32.8\%) of all cases surveyed. In more than three quarters of the of all cases surveyed $n=440(81.6 \%)$ assessed their peers as fraudsters on a continuum from very impressed as an intellectual to that of being impressed as an intellectual as compared to only $\mathrm{n}=99(18.4 \%)$ as somewhat impressed as an intellectual (Table 7).

Table 7: Perceived Actor who is Involved in Fraud

\begin{tabular}{|l|r|r|}
\hline & Frequency & Percent \\
\hline Personality & & \\
\hline Introverted & 172 & 31.9 \\
\hline Extroverted & 367 & 68.1 \\
\hline Level of respect & & \\
\hline
\end{tabular}


International Journal of Advances in Scientific Research and Engineering (ijasre), Vol 7 (8), August -2021

\begin{tabular}{|l|r|r|}
\hline Very well respected & 156 & 28.9 \\
\hline Well respected & 92 & 17.1 \\
\hline Respected & 114 & 21.2 \\
\hline Somewhat respected & 177 & 32.8 \\
\hline Level of intellect & 165 & 30.6 \\
\hline Very impressed as an intellectual & 275 & 51.0 \\
\hline Impressed as an intellectual an & 99 & 18.4 \\
\hline $\begin{array}{l}\text { Somewhat impressed as an } \\
\text { intellectual }\end{array}$ & & \\
\hline
\end{tabular}

\subsection{DISCUSSION}

The purpose of the study was to profile who the typical fraudster was in the general education sector. The fraudster is likely to be a youthful male and has served in the Ministry of General Education for 12 years ( \pm SD 8.9). The typical fraudster is mostly an accountant or a boss who holds a senior management position. The fraudster may commit the fraud once they are comfortable in their job and enjoy the trust and respect of colleagues. The fraudster is deemed to be an extrovert, intelligent and has a high level of education.

It was not expected that females would substantially less involved in fraud and this is consistent with previous research (Beutel and Marini, 1995; Becker et al., 2006; Sörlin et al., 2011; Dellaportas, 2013; Ramamoorti et al., 2013, 2014; Huber, 2016). The possible explanation in this sector could be associated with the possible low numbers of women employed handling finances or in senior management position. Friedrichs (2009) argues that it is widely understood that males greatly outnumber females among conventional crime offenders. He claims that men outnumber women by six to one.

Even when there are women in equal numbers, criminologists agree that the gender gap is universal in crime involvement (Steffensmeier et al., 1996). Women are always and everywhere likely than men to commit criminal acts. Patterns of offending by men and women are notable both for their similarities and differences research (Ramamoorti, 2008; Sörlin et al., 2011; Dellaportas, 2013; Ramamoorti et al., 2013; Huber, 2012, 2016). The other possible explanations for the observed disparity could be that women bosses and accountants in this sector may think more about the consequences of their actions and are generally less impulsive than men (see Buss, 1995; Broidy et al., 1997; Robb, 2006). Research conducted by the Financial Services Authority in the UK in 2001 suggested that men take more financial risks, are more likely than women have. Moreover, women tend to express more ethical responsibility for finances than men. Women's responses to ethical issues might be attributed to the social desirability response bias (Dalton \& Ortegren, 2011; Jaffee and Hyde, 2000).

\subsection{Age of Actor and Crime}

This study meets the crime curve hypothesis. The younger one was the more likely they were to be involved in fraud. The hypothesis age-crime curve, increasing to a peak in the younger people is well-known. Less well-known is that, its variations in prevalence (the proportion of persons who rather than incidence (the rate of offending by offenders). These findings have major implications for fraud prevention and occurrence since the greatest residual length of offending careers, greatest potential incapacitated effect, may be between twenty-five and forty, not at the peak age of 40 . There is some specialization in fraud offending with age, but offending seems to decrease with age in our study. While the form of the curve is widely appreciated, its meaning is not. For example, does the peak in the fraud offending in the under 30 years reflect peak in the number of different offenders, in the number of different types of fraud offenses committed by each offender, or in the number of offenses of each type committed by each offender (or in some combination of these)? Why does the crime perception rate as seen by peers in this study reach a peak in the youthful years, and why does it decline afterward. Just as the answers to substantive questions about the age-crime curve are not widely known, methodological questions are also perplexing.

The answers to this question were not established in this study. Perhaps classical studies by Hirschi and Gottfredson's (1983) critique of social explanations of the empirical relationship between age and crime is an advance on earlier discussions of this relationship in several respects. First, most explanations have focused on the transition between adolescence and adulthood, when involvement in many forms of crime peaks and then begins to decline (Friday and Hage, 1976; Greenberg, 1977, 1983; Glaser, 1978). In "Age and the Explanation of Crime," Hirschi and Gottfredson (1983) point out that involvement in crime does not level 
off during the adult years; instead, it continues to decline with advancing age. This observation directs theoretical attention to the entire life span, not to only one part of it.

Second, Hirschi and Gottfredson (1983) note that the factors that explain the age distribution could be completely different from those that explain how crime varies in relation to other personal traits. Although this is not a parsimonious possibility, it is not logically impossible and should not be ruled out a priori.

We may be compelled to render a new interpretation from what the delinquency literature calls "early age of onset." We are arguing that fraud in the education sector commences just a few years following employment. Noting the existence of a strong negative correlation between age of first involvement in offending and the frequency and severity of offensive acts in later years, we are compelled to believe further that early onset leads to deeper, continuing involvement (Mannheim and Wilkins 1955: 64; Sellin 1958; Wolfgang et al., 1972: 130-50) which plummets as one grows older. Hirschi and Gottfredson (1983) point out that if all groups share a common age distribution, young offenders will be disproportionately drawn from those groups (as seen in this study) whose level of involvement is high, as is true of older offenders. Thus, no special explanation for age of onset is needed, beyond that of why some groups have higher levels of involvement in crime than others.

\subsection{Job type of Fraudster}

This study shows that fraud is committed by bosses and accountants singularly and in a binary form. We can borrow a leaf from Jensen and Meckling (1975). The duo showed that the agency problems arising from the separation of ownership and control in large corporations are not confined to organisational performance but extend to fraud. The incentive for top management to defraud a publicly owned institution in which they have little individual wealth invested may be very different if they were to own it. Ownership differences may also affect the policies and practices of public sector organisations regarding fraud. For instance, even though they may have similar constraints on their financial resources, they may consider the amount of resources committed to the prevention and detection of theft and fraud should not be determined by net cost considerations alone but other criteria as well, e.g. zero tolerance implying a higher level of fraud. The opportunities for fraud within this education sector may vary according to the type and status of the fraudster. A senior figure such as a District Education Board Secretary or head teacher is more likely to have access to greater funds and will have greater scope than a low-level employee as studies on seniority have shown elsewhere (Cullinan and Sutton, 2002). It also follows (assuming that there are sufficient potential fraudsters) that frauds will be perpetrated in the most efficient and effective (even 'optimal') way in terms of risk and return and intelligence. This may involve, not only the way in which it is perpetrated but also the number and identity of the perpetrators. For example, a fraudster may involve (i.e. collude with) others, if necessary, in a scheme if its success requires the use and cooperation of an insider to such an extent that the reduction in risk more than compensates for having to share the reward. This is what seems to be happening in the general education sector.

\subsection{Other attributes of a Fraudster}

Though we did not have an opportunity to assess the fraudster's one aspect of personality as extraverts and introverts, we rely on Eysenck's conceptualisation, extraversion which is the opposite of introversion (Eysenck, 1969: 5-6). In his behavioural account of the typical extravert, we assume that since most of the fraudsters are extroverts, they fit a person who likes parties, craves excitement, takes chances, is carefree, easy-going is not always a reliable person" (Eysenck, 1969: 8). These attributes may fit the assumptions of the fraud triangle and diamond theories when accounting for fraud. Given the high proportion of fraudsters are extroverted and highly respected, such people may become marginally more prepared to introduce fraudulent behaviour into the fraud they commit than they would otherwise. "What it always comes back to is that fraud is about people, what they want and how much resistance they face. This usually comes down to pursuit of a lifestyle that is culturally acceptable to them.

\subsection{Significance and Study Limitations}

The findings outlined in this paper should be considered with a pinch of salt. The findings obtained within this research cannot be generalizable to other the TEVET or higher education sectors in Zambia due to their exclusion in sample. Moreover, the study was cross-sectional in the sense that all relevant data was collected at a single point in time. The reason for preferring a cross-sectional study was due to the vast nature of the study and the limitation of time. And it ought to be noted that obtaining information from a cross-section of a population at a single point in time is a reasonable strategy for pursuing many descriptive researches. The fact that fraudsters may have been part of the study and were only expected to project on others or even they, their views could not be captured expressly. Further than this, a survey questionnaire could not provide the lifeworld experiences of the setting to grant an understanding from the social actors.

\subsection{Policy and Research Implications}

Recognising that fraudsters may have been part of the study and were only expected to project on others or even they, their views could not be captured expressly, it is recommended that a study of fraudsters who may be incarceration be the target for future 
research. It is also recommended to conduct a qualitative inquiry to render lifeworld experiences of the setting to grant an understanding from the social actors' points of view. A combination of qualitative and quantitative approaches could be another option and research could be extended to TEVET or higher education sectors in Zambia.

This study is significant in that it has a scored a first in profiling the attributed of perceived fraudsters which information could be handy for criminologists and for crime prevention. Heads of units in the general education sector are better to work on preparing new entrants to attend training programs on financial management issues. These programmes would create a deterrent experience.

\subsection{CONCLUSION}

The purpose of this paper was to profile who the typical fraudster was in the general education sector. The typical fraudster in the general educational sector could be mostly an accountant or a boss and holds a senior management position. The fraudster may commit the fraud once they are comfortable in their job and enjoy the trust and respect of colleagues. The fraudster is deemed to be an extrovert, intelligent and has a high level of education.

\section{Acknowledgements}

This article is a result of the research within the 2018-2020 doctoral research programmes, from The University of Zambia and Zimbabwe Open University. Our gratitude is to the many individuals who directly or indirectly contributed their unlimited initiation and facilitation in the study.

\section{REFERENCES}

[1] Becker, D., Connolly, J., Lentz, P and Morrison, J. (2006). Using the Business Fraud Triangle to Predict Academic Dishonesty among Business Students. Academy of Educational Leadership Journal (10:1), pp. 37-54.

[2] Beutel, A. M., and Marini, M.M. 1995. Gender and Values. American Sociological Review 60:436-48.

[3] Broidy, L., and Agnew, A. (1997). Gender and Crime: A General Strain Theory Perspective. Journal of Research in Crime and Delinquency 34:275-306.

[4] Byrnes, J. P., Miller, D.C., Schafer, W.D. (1999). Gender Differences in Risk Taking: A Meta-Analysis.” Psychological Bulletin 125:367-83.

[5] Cullina, n C.P, Sutton, S.G. (2002). Defrauding the public interest: a critical examination of reengineered audit process and the likelihood of detecting fraud. Critical Perspectives on Accounting 3: 297-310.

[6] Dalton D., Ortegren M., (2011). Journal of Business Research 103 73-93.

Dellaportas, S. (2013). Conversations with inmate accountants: Motivation, opportunity and the fraud triangle, Accounting Forum, 37 (1), 29-39.

[7] Eysenck, H. (1996). Personality and Crime: Where Do We Stand”, Psychology, Crime and Law, 2008, 3/2, p. 143-152.

[8] Friedrichs D. O., (2009). Trusted Criminals: White Collar Crime in Contemporary Society, Wadsworth, Belmont, CA.

[9] Grice, J. W., Jackson, B. J., \& McDaniel, B. L. (2006). Bridging the Idiographic-Nomothetic Divide: A Follow-Up Study. Journal of Personality, 74, 1191-1218.

[10] Hirschi, T., \& Gottfredson, M. (1983). Age and the explanation of crime. American Journal of Sociology, 89(3), 552-584

[11] Huber, W.D. (2012). Is Forensic Accounting in the United States Becoming a Profession? Journal of Forensic and Investigative Accounting (4:1), pp. 255-284.

[12] Huber, W.D. (2016). Forensic Accounting, Fraud Theory, and the End of the Fraud Triangle, Journal of Theoretical Accounting Research (12:2), pp. 28-48

[13] Jaffee, S., and Hyde J. S. (2000). Gender Differences in Moral Orientation: A Meta-Analysis. Psychological Bulletin 126:703-726.

[14] Jensen, M.C, and Meckling, W.H. (1975). Theory of the firm: managerial behaviour, agency costs and ownership

[15] Klenowski, P. M., Copes, H., Mullins, C.W. (2011). Gender, Identity, and Accounts: How White-Collar Offenders Do Gender When Making Sense of Their Crimes. Justice Quarterly 28:46-69.

16] Larsson, R. (1993). Case survey methodology: Quantitative analysis of patterns across case studies. Academy of Management Journal, 36, 1515-1546. 
17] Putnam, L. (1983). The interpretative perspective: An alternative to functionalism. In L. Putnam, and M. Pacanowsky (Eds.). Communication and organizations, Beverly Hills, CA: Sage.

[18] Ramamoorti, S. (2008). The psychology and sociology of fraud: Integrating the behavioural sciences component into fraud and forensic accounting curricula. Issues in Accounting Education, 23 (4), 521-533.

[19] Ramamoorti, S., Morrison, D., and Koletar, J.W. (2014). Bringing Freud to Fraud. Journal of Forensic \& Investigative Accounting (6:1) pp. 47-81.

[20] Ramamoorti, S., Morrison, D., Koletar, J.W., and Pope, K. R. (2013). A.B.C.'s of Behavioural Forensics: Applied Psychology to Financial Fraud Prevention and Detection, Hoboken, NJ: John Wiley \& Sons.

[21] Sörlin A., Ohman A., Blomstedt Y., Stenlund H., Lindholm L., (2011). Gender in Management: An International Journal 26 (4) $275-288$.

[22] Steffensmeier, D. J. and Emilie, A. (1996). Gender and Crime: Toward a Gendered Theory of Female Offending. Annual Review of Sociology. 22:459-87.

[23] Yamane, Taro. (1967). Statistics: An Introductory Analysis, 2nd Ed., New York: Harper and Row. P.886.

*Corresponding author: ngosa.paul@gmail.com 